Division of Geological \& Geophysical Surveys

RAW-DATA FILE 2016-4

\title{
CORE FRAGMENT DESCRIPTIONS, EXXON CORE HOLES, UPLANDS BORDERING YUKON FLATS BASIN, EAST-CENTRAL ALASKA
}

by

David L. LePain and Simone Montayne

2017

$\$ 2.00$

THIS REPORT HAS NOT BEEN REVIEWED FOR

TECHNICAL CONTENT OR FOR CONFORMITY TO THE

EDITORIAL STANDARDS OF DGGS

\author{
Released by: \\ STATE OF ALASKA \\ DEPARTMENT OF NATURAL RESOURCES \\ Division of Geological \& Geophysical Surveys \\ 3354 College Road \\ Fairbanks, Alaska 99709-3707
}




\title{
CORE FRAGMENT DESCRIPTIONS, EXXON CORE HOLES, UPLANDS BORDERING YUKON FLATS BASIN, EAST-CENTRAL ALASKA
}

\author{
by \\ David L. LePain ${ }^{1}$ and Simone Montayne ${ }^{1}$
}

\section{INTRODUCTION}

This Raw Data File provides lithologic descriptions of core fragments recovered from a series of core holes drilled by Exxon (mid-'80s) in the uplands bordering the Yukon Flats basin. In addition to descriptions of the material, the tabulated file includes geographic location, core hole numbers, an age estimate, core fragment depth, general lithology, grain size, and facies interpretation. The author examined these core materials in Fairbanks during winter and spring 2002. This work was done in preparation for an assessment carried out by the U.S. Geological Survey (Stanley and others, 2004) of undiscovered, technically recoverable hydrocarbon resources in the Yukon Flats basin.

The data table associated with this report are available in digital format as a comma-separated values (CSV) file. Additional details about the organization of information and grain size classification codes used in the table are noted the accompanying metadata file. Core hole locations are shown on an accompanying map (sheet 1). All files can be downloaded from the DGGS website (ttp://doi.org/10.14509/29576).

\section{DOCUMENTATION OF METHODS}

Core fragments where recovered from a series of core holes drilled by Exxon. Drilling crews placed core fragments in muslin sample bags marked with the core hole number, depth (feet), and estimated age of each core fragment. Some sample bags were annotated with additional location information, such as a stream name. Sample bags were grouped in cardboard boxes labeled with a box number and transported to an offsite warehouse for subsequent examination.

A ten power (10X) hand lens and standard grain size comparator were used to examine core materials. Dilute hydrochloric acid $(\mathrm{HCl})$ was used to check for calcite and dolomite content. For each sample bag, the author provided a general rock type classification, noted the grain size range according to the Wentworth classification scale (Wentworth, 1922), provided a comprehensive description, and when possible, an interpretation of the depositional facies.

Paper copies of USGS topographic maps showing core hole locations were provided to the USGS by Doyon, Limited. Maps were scanned, imported into ArcGIS, and georeferenced by USGS staff to provide the latitude and longitude values (NAD27) of each core hole surface intercept. The resulting location information is included in the data table, along with all sample bag annotations and core fragment descriptions. Any sample age information included in the table was obtained from the annotations on the sample bag. Users should note that no effort was made to verify the accuracy of the information on the sample bags.

\footnotetext{
${ }^{1}$ Alaska Division of Geological \& Geophysical Surveys, 3354 College Rd., Fairbanks, AK 99709-3707
} 


\section{ACKNOWLEDGMENTS}

In addition to the core fragment descriptions provided in the RDF, reconnaissance fieldwork was done in support of the USGS assessment. The field team included Rick Stanley (USGS party chief), Jim Clough (DGGS), David LePain (DGGS), and Rocky Reifenstuhl (DGGS). Reifenstuhl (2006) examined thinsections of selected core fragments and surface samples from outcrops bordering Yukon Flats basin. LePain (2016 [in process]) briefly described selected outcrops visited by the field team. Core samples belong to the Doyon Native regional corporation and, at the time of this writing, are stored in Fairbanks, Alaska. Doyon, Limited, gave DGGS permission to examine the core fragments. Mike Tolbert of Taiga Ventures provided core fragment layout space in the Taiga Ventures office in Fairbanks, and Chris Puchner introduced LePain to the core material. Funding for DGGS's work on this project was provided by the State of Alaska.

\section{REFERENCES}

LePain, D.L., and Stanley, R.G., 2017, Reconnaissance sedimentology of selected tertiary exposures in the upland region bordering the Yukon Flats basin, east-central Alaska: Alaska Division of Geological \& Geophysical Surveys Preliminary Interpretive Report 2016-6, 14 p. http://doi.org/10.14509/29700

Reifenstuhl, R.R., 2006, Yukon Flats basin, Alaska: Reservoir characterization study: Alaska Division of Geological \& Geophysical Surveys Report of Investigation 2006-1, 25 p. http://doi.org/10.14509/14910

Stanley, R.G., Ahlbrandt, T.S., Charpentier, R.R., Cook, T.A., Crews, J.M., Klett, T.R., Lillis, P.G., Morin, R.L., Phillips, J.D., Pollastro, R.M., Rowan, E.L., Saltus, R.W., Schenk, C.J., Simpson, M.K., Till, A.B., and Troutman, S.M., 2004, Oil and gas assessment of Yukon Flats, east-central Alaska, 2004: U.S. Geological Survey Fact Sheet 2004-3121, 2 p. http://pubs.usgs.gov/fs/2004/3121/

Till, A. B., Dumoulin, J.A., Phillips, J.D., Stanley, R.G., and Crews, J., 2006, Generalized bedrock geologic map, Yukon Flats region, east-central Alaska: U.S. Geological Survey Open-File Report 2006-1304, 1 sheet, scale 1:500,000. http://pubs.usgs.gov/of/2006/1304/

Wentworth, C.K., 1922, A scale of grade and class terms for clastic sediments: Journal of Geology, v. 30, no. 5, p. 377-392. http://www.jstor.org/stable/30063207

Wilson, F.H., Hults, C.P., Mull, C.G., and Karl, S.M., 2015, Geologic map of Alaska: U.S. Geological Survey Scientific Investigations Map 3340, 2 sheets, scale 1:584,000. doi:10.3133/sim3340 